\title{
The carbon cycle in the continental lithosphere and the generation of alkaline mafic melts in cratonic and rift regions
}

\author{
Stephen F. Foley ${ }^{1}$ and Tobias P. Fischer ${ }^{2}$ \\ ${ }^{1}$ ARC Centre of Excellence for Core to Crust Fluid Systems and Department of Earth and Planetary Sciences, \\ Macquarie University, North Ryde, New South Wales, Australia \\ ${ }^{2}$ Department of Earth and Planetary Sciences, University of New Mexico, Albuquerque, New Mexico, U.S.A.
}

The generation of many continental alkaline magmas, including kimberlites, carbonatites, ultramafic lamprophyres, nephelinites and melilitites requires the presence of $\mathrm{CO}_{2}$ or carbonates in the source region. These rocks are strongly associated with cratonic lithosphere and particularly with continental rifts in proximity to cratons, where high concentrations of carbonatites occur. However, the origin of the large amounts of $\mathrm{CO}_{2}$ needed to explain these occurrences remains largely unexplained. Here, we consider the question of where these huge concentrations of carbon come from, and how they are reactivated to result in the generation of strongly alkaline, silica-undersaturated magmas.

In recent years, great strides have been made in understanding the deep carbon cycle, but this has concentrated on the behaviour of carbon during release at the surface as $\mathrm{CO}_{2}$ degassing through mid ocean ridges and coean islands, and on the complex mechanisms of the return of carbon to the mantle at subduction zones (Dasgupta and Hirschmann, 2010; Kelemen and Manning, 2015). The timeintegrated storage and re-release of carbon from the continental lithosphere has not been adequately quantified in global models. Recent work on outgassing at rifts has found that enormous amounts of $\mathrm{CO}_{2}$ are passively released, much of it along faults. Extrapolations from the Natron-Magadi basin close to the Kenya-Tanzania border, where carbonate-rich magmatism is abundant, to the whole rift results in an estimate of around $52 \mathrm{Mt} \mathrm{C/yr}$ (Lee et al., 2016), higher than most estimates for mid ocean ridges (8-53) and island arcs (18-43) (Dasgupta and Hirschmann, 2010; Kelemen and Manning, 2015; Kagoshima et al., 2015). Later measurements at rift volcanoes as far north as Ethiopia (Hutchison et al., 2016) indicate that this value may be too low, as degassing close to volcanoes may be much higher than previously thought. $\mathrm{He}$ and $\mathrm{C}$ isotope studies indicate that much of the $\mathrm{CO}_{2}$ degassed along faults originates in the mantle.

\section{Carbonate in continental alkaline igneous rocks}

Carbon in continental rifts is not restricted to passive $\mathrm{CO}_{2}$ release: large concentrations of carbonaterich magmas solidify as carbonatites, kimberlites, ultramafic lamprophyres (UML), nephelinites, melilitites, basanites, and their plutonic equivalents. The high volume of these magmas in rifts and their rarity elsewhere attests to a large reservoir of carbon beneath rifts. Although carbonatites at localities such as Oldoinyo Lengai probably originate by liquid immiscibility at upper crustal pressures from melilitite or nephelinite, the extreme $\mathrm{CO}_{2}$ release at Nyiragongo (Burton et al., 2013) demonstrates that nephelinites also preferentially tap $\mathrm{CO}_{2}$-rich sources. Furthermore, melilitites and nephelinites are characteristically concentrated at the propagating tips of rifts and along their flanks where the lithosphere is thickest (Foley et al., 2012), and are replaced by voluminous basaltic magmatism in the rift axes as the rift matures.

In the East African Rift, ultramafic, potassium- and carbonate-rich melts including kimberlites, kamafigutes and carbonatites are associated with the Tanzanian craton lithosphere, which is consistent with experiments showing that low-degree melts range from carbonatite to UML at depths of 130$200 \mathrm{~km}$ (Foley et al., 2009). The kamafugites are closely related to UML (aillikites and alnöites) found in similar positions on other continents (Foley et al., 2002; Tappe et al., 2008). Beneath the thick cratons, melts are also characterised by high $\mathrm{K} / \mathrm{Na}$ because of the abundance of phlogopite in rocks such as carbonated phlogopite pyroxenite in addition to peridotite (Tappe et al., 2008).

These carbon-rich sources are repeatedly tapped: most carbonatites in East Africa were emplaced in the last 40Ma (Woolley and Kjarsgaard, 2008), but earlier episodes at $123-133 \mathrm{Ma}$ and $1040 \mathrm{Ma}$ 
indicate a recurrence of $\mathrm{CO}_{2}$-rich magmatism, which is also seen in Labrador/Greenland and South Africa (Boyd and Gurney, 1986; Tappe et al., 2007).

\section{Mechanisms of carbon storage and release and the magnitude of their effects}

The incorporation of carbon into, and its later release from, the continental lithosphere involves its incorporation during lithosphere formation, accumulation from degassing of the deeper mantle over time, and the remobilization of carbon within the lithosphere by the movement of incipient melts.

Despite its relatively restricted areal extent, the great thickness of the cratonic mantle means that it makes up slightly more than half of the continental mantle lithosphere. The formation mechanisms of cratonic lithosphere are debated, with possibilities including accumulation at subduction zones, lateral accretion, and vertical accretion from plumes beneath thick volcanic plateaux (Lee 2006). The age of continental crust and the size of cratonic blocks at different times in the Archean is also controversial. If two thirds of the current crust existed by the end of the Archean and this was underlain and stabilised by strongly depleted lithosphere, then the preferred picture of the cratonic lithosphere is blocks of deep, depleted lithosphere in which magmatism is associated with reactivation along margins and deep fault zones (Foley, 2008; Griffin et al., 2013). This picture is compatible with the long-known association of kimberlites and deep fault zones known as Clifford's Rule. An important corollary of this model is that strongly depleted, deep lithosphere provides a strongly reduced environment that forms a redox trap for diamonds (Foley, 2011; Rohrbach and Schmidt, 2011) during later melt movements. We estimate that a lithospheric carbon content of $0.25 \mathrm{Mt} \mathrm{C} \mathrm{km}^{-3}$ would result from subduction wedge accretion, whereas ten times this figure could result from vertical accretion of plumes. These values are poorly constrained because of uncertainties surrounding the oxidation state of the atmosphere and near-surface processes, the probably more limited volume of organic material and carbonate sediments in the Archean, and the amount of recycled material in plumes. However, all estimates are insignificant relative to the carbon introduced during later enrichment processes.

Carbon introduced into the lithosphere by gradual, continuous enrichment is estimated based on methods used for $\mathrm{CO}_{2}$ output at mid-ocean ridges, modified for an incipient melting zone between 300 and $200 \mathrm{~km}$ depth and an average lithosphere age of $2809 \mathrm{Ma}$ for the cratons. Restricting the accumulation of this carbon to the loweest $5-10 \%$ of the lithosphere, and allowing for $50 \%$ removal of the lithosphere base by later small-scale convective erosion, this results in $14-28 \mathrm{Mt} \mathrm{C} / \mathrm{km}^{-3}$. We estimate the amount of carbon scavenged from plumes by assuming passage of a plume every 675 million years, based on the average periodicity of alkaline magmatism in incipient rifts, and using the model for the volatile content of plumes of Sobolev et al. (2011). This results in three phases of enrichment by plumes for average cratonic lithosphere, adding 40-45 $\mathrm{Mt} \mathrm{C} \mathrm{km}^{-3}$ to the basal layers of the lithosphere. After the overprinting of the original carbon content by both gradual degassing and plume enrichment, the lower cratonic lithosphere contains $57-71 \mathrm{Mt} \mathrm{C} \mathrm{km}^{-3}$, or $1.6-3.2 \mathrm{wt} \% \mathrm{CO}_{2}$.

Carbon is sequestered in the lower lithosphere as diamonds and dyke assemblages; only a small amount probably exists as carbonated peridotite. It is initially trapped by redox freezing, because the deep cratonic mantle is initially extremely reduced due to extreme depletion and to the pressure effect on oxygen fugacity (Foley, 2011; Rohrbach and Schmidt, 2011). However, the influx of later melts oxidises the lithosphere by up to 4 orders of magnitude $\mathrm{fO}_{2}$ (Yaxley et al., 2017). Remobilisation is initially by redox melting, as the oxidation process remobilises carbon as dissolved carbonate in incipient melts that are carbonatitic to aillikitic with higher $\mathrm{CO}_{2}$ contents than kimberlites. It is notable here that aillikites and carbonatites are associated with rifts, unlike kimberlites, which may be derived largely from the asthenosphere. These low- $\mathrm{SiO}_{2}$ incipient melts are very mobile are effective in the redistribution of carbon long before decompression melting becomes more important at later stages of rifting when the lithosphere is thinned and blocks become delaminated. Repeated plumetriggered melt incursions identify structural weaknesses that focus later melts, eventually forming enriched zones that reach high into the lithosphere beneath later rift locations. Lithosphere blocks may weaken and founder, breaking off blocks and eroding the lithosphere. However, carbon in delaminated blocks will re-melt and migrate upwards as carbonate, forming assemblages that are less 
dense (2.95-3.2 $\mathrm{g} \mathrm{cm}^{-3}$ ) than peridotite and so contribute to later magmatism. Re-melting of the subrift enriched zone produces melts charged with carbonate, bringing sufficient $\mathrm{CO}_{2}$ towards the surface to feed volcanoes and fault zones that emit 28-34 Mt C/year along the length of the East African Rift for the entire $40 \mathrm{Myr}$ lifespan of a continental rift. Given the uncertainties in many input parameters for these calculations, the value of 28-34 Mt C/year is remarkably similar to the $52 \mathrm{Mt} \mathrm{C} / \mathrm{yr}$ estimated from passive degassing for the East African rift (Lee et al., 2016).

\section{References}

Boyd FR, Gurney JJ (1986) Diamonds and the African lithosphere. Science 272: 472-477

Burton MR, Sawyer GM, Granieri D (2013) Deep carbon emissions from volcanoes. Rev. Mineral. Geochem. 75: 323-354

Dasgupta R, Hirschmann MM (2010) The deep carbon cycle and melting in Earth's interior. Earth Planet. Sci. Lett. 298: 1-13

Foley SF (2008) Rejuvenation and erosion of the cratonic lithosphere. Nature Geosci. 1: 503-510

Foley SF (2011) A reappraisal of redox melting in the Earth's mantle as a function of tectonic setting and time . J. Petrol. 52: 1363-1391

Foley SF, Andronikov AV, Melzer S (2002) Petrology, geochemistry and mineral chemistry of ultramafic lamprophyres from the Jetty Peninsula area of the Lambert-Amery Rift, Eastern Antarctica. Mineral. Petrol. 74: 361-384

Foley SF, Yaxley GM, Rosenthal A, Buhre S, Kiseeva ES, Rapp RP, Jacob DE (2009) The composition of near-solidus melts of peridotite in the presence of $\mathrm{CO}_{2}$ and $\mathrm{H}_{2} \mathrm{O}$ at $40-60 \mathrm{kbar}$. Lithos 112S: 274-283

Foley SF, Link K, Tiberindwa JV, Barifaijo E (2012) Patterns and origin of igneous activity around the Tanzanian craton. J. Afr. Earth Sci. 62: 1-18

Griffin WL, Begg GC, O'Reilly SY (2013) Continental-root control on the genesis of magmatic ore deposits. Nature Geosci. 6: 905-910

Hutchison W, Biggs J, Mather TA, Pyle DM, Lewi E, Yirgu G, Caliro S, Chiodini G, Clor LE, Fischer TP (2016) Causes of unrest at silicic calderas in the East African Rift: new constraints from InSAR and soil-gas chemistry at Aluto volcano, Ethiopia. Geochem. Geophys. Geosys. 17: doi: 10.1002/2015GC06395

Kagoshima T, Sano Y, Takahata N, Maruoka T, Fischer TP, Hattori K (2017) Sulphur geodynamic cycle. Scientific Reports 5:8330

Kelemen PB, Manning CR (2015) Reevaluating carbon fluxes in subduction zones, what goes down, mostly comes up. Proc. Nat. Acad. Sci. 112: E3997-E4006

Lee C-TA (2006) Geochemical/petrologic constraints on the origin of cratonic mantle. Geophys. Monograph Series 164: 89-114

Lee H, Muirhead JD, Fischer TP, Ebinger CJ, Kattenhorn SA, Sharp ZD, Kianji G (2016) Massive and prolonged deep carbon emissions associated with continental rifting. Nat. Geosci. 9: 145-149

Rohrbach A, Schmidt MW (2011) Redox freezing and melting in the Earth's deep mantle resulting from carbon-iron redox coupling. Nature 472: 209-212.

Sobolev SV, Sobolev AV, Kuzmin DV, Krivolutskaya NA, Petrunin AG, Arndt NT, Radko VA, Vasiliev YR (2011) Linking mantle plumes, large igneous provinces and environmental catastrophes. Nature 477: 312-316

Tappe S, Foley SF, Stracke A, Romer RL, Heaman LM, Kjarsgaard BA, Joyce N (2007) Craton reactivation on the Labrador Sea margins: ${ }^{40} \mathrm{Ar} /{ }^{39} \mathrm{Ar}$ age and $\mathrm{Sr}-\mathrm{Nd}-\mathrm{Hf}-\mathrm{Pb}$ isotope constraints from alkaline and carbonatite intrusives. Earth Planet. Sci. Lett. 256: 433-454.

Tappe S, Foley SF, Kjarsgaard BA, Romer RL, Heaman LM, Stracke A, Jenner GA (2008) Between carbonatite and lamproite - diamondiferous Torngat ultramafic lamprophyres formed by carbonate fusion melting of cratonic MARID-type metasomes. Geochim. Cosmochim. Acta 72: 3258-3286.

Woolley AR, Kjarsagaard BA (2008) Carbonatite occurrences of the world: map and database. Geological Survey of Canada Open File 5796

Yaxley GM, Berry AJ, Rosenthal A, Woodland AB, Paterson D (2017) Redox preconditioning deep cratonic lithosphere for kimberlite genesis - evidence from the central Slave Craton. Scientific Reports 7: 30 